\title{
Hepatic Leukemia Factor
}

National Cancer Institute

\section{Source}

National Cancer Institute. Hepatic Leukemia Factor. NCI Thesaurus. Code C97558.

Hepatic leukemia factor (295 aa, $\sim 33 \mathrm{kDa}$ ) is encoded by the human HLF gene. This protein is involved in both DNA binding and the regulation of transcription. 